\title{
Divestasi Saham Asing dalam Penambangan Bawah Tanah Dihubungkan dengan Kedaulatan Negara*
}

\author{
Purnama Trisnamansyah" $^{* *}$ dan Yusuf Saepul Zamil ${ }^{* * *}$
}

\begin{abstract}
Abstrak
Peraturan Pemerintah Nomor 77 Tahun 2014 tentang Perubahan Ketiga atas Peraturan Pemerintah Nomor 23 Tahun 2010 tentang Pelaksanaan Kegiatan Usaha Pertambangan Mineral dan Batu bara secara eksplisit menentukan bahwa pemegang Izin Usaha Pertambangan dan Izin Usaha Pertambangan Khusus setelah lima tahun sejak berproduksi wajib melakukan divestasi saham secara bertahap kepada peserta nasional paling sedikit $30 \%$ (tiga puluh persen). Artikel ini menjelaskan bagaimana implikasi ketentuan divestasi saham tersebut terhadap partisipasi peserta nasional dan menganalisa dari sudut pandang kedaulatan negara dalam penguasaan dan pengelolaan sumber daya alam. Metode yang digunakan adalah deskriptif analitis dengan pendekatan yuridis normatif. Melalui ketentuan divestasi saham ini, 70\% (tujuh puluh persen) saham tetap dapat dimiliki oleh penanam modal asing. Dengan demikian, peserta nasional tetap sebagai pemegang saham minoritas. Semestinya negara melalui keterlibatan peran pemerintah, pemerintah daerah, BUMN, BUMD atau badan usaha swasta menjadi pemegang saham mayoritas sebagai cerminan dari penguasaan dan pengelolaan sumber daya alam nasional.
\end{abstract}

Kata kunci: Divestasi, Kedaulatan Ekonomi, Penambangan, Penanam Modal, Saham.

\section{Divestment of Foreign Shares in the Underground Mining in Correlation with the State Sovereignty}

\begin{abstract}
Government Regulation Number 77 of 2014 on Third Amendment to Government Regulation Number 23 of 2010 concerning the Implementation of Mineral and Coal Mining explicitly specify that the holder of Mining Business License (IUPK) Production Operations and Special Mining Business License (IUPK) Production Operations in FDI, after five years of production must divest the shares gradually to the national participants at least $30 \%$ of the total shares. This article discusses the implication of divestment provision to national participants and analyse it from the perspective of natural resources control and management by the state. Research methodology used in this article is normative juridical approach. Under this divestment provision, 70\% (per cent) of shares still can be owned by foreign investors. Thus,

PADJADJARAN Jurnal IImu Hukum Volume 3 Nomor 3 Tahun 2016 [ISSN 2460-1543] [e-ISSN 2442-9325]

* $\quad$ Artikel ini disarikan dari penelitian: "Analisis Hukum PP No. 77 Tahun 2014 Mengenai Kewajiban Divestasi Saham PMA pada Penambangan Bawah Tanah Ditinjau dari Kedaulatan Negara atas Pertambangan" yang didanai melalui Dana DIPA BLU Universitas Padjadajaran Tahun Anggaran 2015.

** Dosen Fakultas Hukum Universitas Padjadjaran, Jalan Dipati Ukur No.35 Bandung, purnama.trisnamansyah@unpad.ac.id, S.H., M.H. (Universitas Padjadjaran).

*** Dosen Fakultas Hukum Universitas Padjadjaran, Jl. Dipati Ukur No.35 Bandung, yusuf@unpad.ac.id., S.H., M.H. (Universitas Padjadjaran).
\end{abstract}


national participants would still be minority shareholders. Supposedly, the state through the involvement role of the state government, local government, state-owned enterprises, local government-owned enterprises or private enterprises, could become the majority shareholders as the reflection of control and management of national resources by the state.

Keywords: Divestment, State Economic Sovereignty, Mining, Investor, Shares.

\section{A. Pendahuluan}

Pertambangan merupakan sebagian atau seluruh tahapan kegiatan dalam rangka penelitian, pengelolaan, pengusahaan mineral atau batu bara yang meliputi penyelidikan umum, eksplorasi, studi kelayakan, konstruksi, penambangan, pengolahan dan pemurnian, pengangkutan dan penjualan, serta kegiatan pasca tambang. ${ }^{1}$ Undang-Undang Nomor 4 Tahun 2009 tentang Pertambangan Mineral dan Batu Bara (UU Minerba) memberikan pengertian mengenai pertambangan mineral yaitu pertambangan kumpulan mineral yang berupa bijih atau batuan, di luar panas bumi, minyak dan gas bumi, serta air tanah (Pasal 1 angka (4)), dan pertambangan batu bara adalah pertambangan endapan karbon yang terdapat di dalam bumi, termasuk bitumen padat, gambut dan batuan aspal (Pasal 1 angka (6)).

Pasal 33 ayat (3) Undang-Undang Dasar 1945 (UUD 1945), menegaskan bahwa bumi, air dan kekayaan alam yang terkandung didalamnya dikuasai oleh negara dan dipergunakan untuk sebesar-besar kemakmuran rakyat. Mengingat mineral dan batu bara sebagai kekayaan alam yang terkandung di dalam bumi merupakan sumber daya alam yang tak terbarukan, pengelolaannya perlu dilakukan seoptimal mungkin, efisien, transparan, berkelanjutan dan berwawasan lingkungan, serta berkeadilan agar memperoleh sebesar-besar bagi kemakmuran rakyat secara

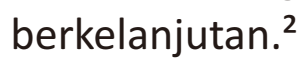

Untuk pengusahaan mineral dan batu bara, pemerintah memberikan kesempatan kepada badan usaha yang berbadan hukum Indonesia, koperasi, perseorangan, maupun masyarakat setempat untuk melakukan pengusahaan mineral dan batu bara berdasarkan izin, yang sejalan dengan otonomi daerah, diberikan oleh pemerintah dan/atau pemerintah daerah sesuai dengan kewenangannya masing-masing. ${ }^{3}$ Berdasarkan ketentuan pasal ini, maka dalam rangka pengusahaan mineral dan batu bara, pemerintah memberikan kesempatan kepada badan usaha yang berbadan hukum Indonesia, koperasi, perseorangan, maupun masyarakat setempat. Dalam rangka memberikan kesempatan kepada badan-badan usaha nasional untuk berpartisipasi dalam pengusahaan mineral dan

Pasal 1 Angka (1) Undang-Undang Nomor 4 Tahun 2009 tentang Pertambangan Mineral dan Batu Bara (UU Minerba).

2 Penjelasan Umum UU Minerba.

3 Pokok Pikiran ke-2 dalam Penjelasan atas UU Minerba. 
batu bara nasional dilakukan melalui divestasi saham milik penanaman modal asing yang melakukan pengusahaan pertambangan mineral dan batu bara nasional.

UU Minerba yang menyatakan bahwa setelah lima tahun berproduksi, badan usaha pemegang Izin Usaha Pertambangan (IUP) dan Izin Usaha Pertambangan Khusus (IPUK) yang sahamnya dimiliki oleh pihak asing wajib melakukan divestasi saham pada pemerintah, pemerintah daerah, badan usaha milik negara, badan usaha milik daerah, atau badan usaha swasta nasional (Pasal 112 ayat (1) UU Minerba). Ketentuan lebih lanjut mengenai divestasi saham sebagaimana dimaksud pada ayat (1) diatur dengan Peraturan Pemerintah (Pasal 112 ayat (2) UU Minerba).

Peraturan Pemerintah yang memuat ketentuan divestasi saham sebagai pelaksanaan dari Pasal 112 UU Minerba telah beberapa kali diubah, terakhir kali diubah melalui Peraturan Pemerintah Nomor 77 Tahun 2014 tentang Perubahan Ketiga atas Peraturan Pemerintah Nomor 23 Tahun 2010 tentang Pelaksanaan Kegiatan Usaha Pertambangan Mineral dan Batubara (PP 77/2014). PP 77/2014 dalam Pasal 7C menentukan bahwa "Pemegang IUP dan IUPK yang melakukan perubahan status perusahaan dari penanaman modal dalam negeri menjadi penanaman modal asing, kepemilikan saham asingnya paling banyak:

1. $75 \%$ (tujuh puluh lima persen) untuk IUP Eksplorasi dan IUPK Eksplorasi;

2. $49 \%$ (empat puluh sembilan persen) untuk IUP Operasi Produksi dan IUPK Operasi Produksi yang tidak melakukan sendiri kegiatan pengolahan dan/atau pemurnian;

3. $60 \%$ (enam puluh persen) untuk IUP Operasi Produksi dan IUPK Operasi Produksi yang melakukan sendiri kegiatan pengolahan dan/atau pemurnian; dan;

4. $70 \%$ (tujuh puluh persen) untuk IUP Operasi Produksi dan IUPK Operasi Produksi yang melakukan kegiatan penambangan dengan menggunakan metode penambangan bawah tanah".

Ketentuan dalam divestasi saham sebagaimana dimaksud dalam Pasal 7C PP 77/2014 tersebut telah mengubah ketentuan mengenai besar komposisi saham yang wajib dilakukan divestasi saham oleh badan usaha penanaman modal asing kepada peserta nasional bagi pemegang IUP Operasi Produksi dan IUPK Operasi Produksi dalam rangka penanaman modal asing. Sebelum diterbitkannya PP 77/2014, pemerintah menerbitkan Peraturan Pemerintah Nomor 23 Tahun 2010 tentang Pelaksanaan Kegiatan Usaha Pertambangan Mineral dan Batu Bara (PP $23 / 2010$ ) yang memuat ketentuan mengenai divestasi saham bagi badan usaha penanaman modal asing, yaitu sebagaimana dimuat dalam Pasal 97 ayat (1), bahwa "modal asing pemegang IUP dan IUPK setelah 5 (lima) tahun sejak berproduksi wajib melakukan divestasi sahamnya, sehingga sahamnya paling sedikit $20 \%$ (dua puluh persen) dimiliki peserta Indonesia". Berdasarkan ketentuan PP 23/2010, kewajiban divestasi saham oleh badan usaha penanaman modal asing minimal $20 \%$ (dua puluh 
persen), dengan makna lain bahwa peserta nasional minimal memiliki 20\% (dua puluh persen) saham badan usaha penanaman modal asing pemegang IUP dan IUPK setelah lima tahun sejak berproduksi.

Melalui Peraturan Pemerintah Nomor 24 Tahun 2012 tentang Perubahan atas Peraturan Pemerintah Nomor 23 Tahun 2010 tentang Pelaksanaan Kegiatan Usaha Pertambangan Mineral dan Batu Bara (PP 24/2012), bahwa "Pemegang IUP dan IUPK dalam rangka penanaman modal asing, setelah 5 (lima) tahun sejak berproduksi wajib melakukan divestasi sahamnya paling sedikit 51\% (lima puluh satu persen) dimiliki peserta Indonesia" (Pasal 97 ayat (1)). Kepemilikan peserta Indonesia sebagaimana dimaksud pada ayat (1), dalam setiap tahun setelah akhir tahun kelima sejak produksi tidak boleh kurang dari persentase sebagai berikut: a. tahun keenam 20\% (dua puluh persen); b. tahun ketujuh 30\% (tiga puluh persen); c. tahun kedelapan 37\% (tiga puluh tujuh persen); d. tahun kesembilan $44 \%$ (empat puluh empat persen); e. tahun kesepuluh 51\% (lima puluh satu persen), dari jumlah seluruh saham (Pasal 97 ayat (2)). Mengacu pada ketentuan divestasi saham menurut PP 24/2014, maka peluang partisipasi peserta nasional dalam usaha pertambangan mineral dan batu bara menjadi lebih besar, karena sekurangkurangnya 51\% (lima puluh satu persen) saham bagi pemegang IUP dan IUPK dalam rangka penanaman modal asing wajib dialihkan kepada peserta nasional pada tahun ke sepuluh.

Dalam perkembangannya, ketentuan mengenai divestasi saham oleh penanam modal asing kepada peserta nasional dalam usaha pertambangan mineral dan batu bara kembali diubah oleh Pemerintah melalui PP 77/2014. Pasal 97 ayat (1) PP 77/2014 menentukan bahwa "Pemegang IUP Operasi Produksi dan IUPK Operasi Produksi dalam rangka penanaman modal asing, setelah 5 (lima) tahun sejak berproduksi wajib melakukan divestasi saham secara bertahap".

PP 77/2014 mengelompokkan besarnya persentase saham asing yang wajib dialihkan kepada peserta nasional bagi pemegang IUP Operasi Produksi dan IUPK Produksi sebagai berikut:

1. Pemegang IUP Operasi Produksi dan IUPK Operasi Produksi yang tidak melakukan sendiri kegiatan pengolahan dan/atau pemurnian, setelah akhir tahun kelima sejak berproduksi paling sedikit sebagai berikut: a. tahun keenam $20 \%$ (dua puluh persen); b. tahun ketujuh $30 \%$ (tiga puluh persen); c. tahun kedelapan $37 \%$ (tiga puluh tujuh persen); d. tahun kesembilan $44 \%$ (empat puluh empat persen); dan e. tahun kesepuluh $51 \%$ (lima puluh satu persen), dari jumlah seluruh saham;

2. Pemegang IUP Operasi Produksi dan IUPK Operasi Produksi yang melakukan sendiri kegiatan pengolahan dan/atau pemurnian, setelah akhir tahun kelima sejak berproduksi paling sedikit sebagai berikut: a. tahun keenam 20\% (dua 
puluh persen); b. tahun kesepuluh 30\% (tiga puluh persen); dan c. tahun kelima belas $40 \%$ (empat puluh persen), dari jumlah seluruh saham;

3. Pemegang IUP Operasi Produksi dan IUPK Operasi Produksi yang melakukan kegiatan penambangan dengan menggunakan metode penambangan bawah tanah, setelah akhir tahun kelima sejak berproduksi paling sedikit sebagai berikut: a. tahun keenam $20 \%$ (dua puluh persen); b. tahun kesepuluh $25 \%$ (dua puluh lima persen); dan c. tahun kelima belas 30\% (tiga puluh persen), dari jumlah seluruh saham;

4. Pemegang IUP Operasi Produksi dan IUPK Operasi Produksi yang melakukan kegiatan penambangan dengan menggunakan metode penambangan bawah tanah dan penambangan terbuka, setelah akhir tahun kelima sejak berproduksi paling sedikit sebagai berikut: a. tahun keenam 20\% (dua puluh persen); b. tahun kedelapan $25 \%$ (dua puluh lima persen); dan c. tahun kesepuluh $30 \%$ (tiga puluh persen), dari jumlah seluruh saham.

Melalui PP 77/2014, bagi penanam modal asing yang menjadi pemegang IUP Operasi Produksi dan IUPK Operasi Produksi yang melakukan kegiatan penambangan dengan menggunakan metode penambangan bawah tanah hanya diwajibkan melakukan divestasi sahamnya paling sedikit 30\% (tiga puluh persen) dari jumlah seluruh sahamnya pada tahun kelima belas. Penanam modal asing pemegang IUP Operasi Produksi dan IUPK Operasi Produksi yang melakukan kegiatan penambangan dengan menggunakan metode penambangan bawah tanah memiliki peluang untuk tetap dapat memiliki saham sebanyak $70 \%$ (tujuh puluh persen), dari jumlah seluruh saham, sedangkan di pihak lain yaitu peserta nasional, pada tahun kelima belas, jika penanam modal asing tetap memiliki sahamnya secara maksimal menurut ketentuan PP 77/2014, maka sisanya hanya 30\% (tiga puluh persen) saham dari jumlah seluruh saham yang dapat dimiliki oleh peserta nasional.

Terkait dengan hal tersebut, perlu diketahui bagaimana implikasi ketentuan divestasi saham penanaman modal asing dalam penambangan bawah tanah menurut PP 77/2014 terhadap partisipasi peserta nasional dan bagaimana jika hal ini dilihat dari sudut pandang kedaulatan negara dalam penguasaan dan pengelolaan sumber daya alam.

\section{B. Metodologi}

Objek penelitian ini adalah divestasi saham bagi penanam modal asing pada penambangan bawah tanah di dalam PP 77/2014, dengan demikian pendekatan yang digunakan adalah yuridis normatif. Data dititik beratkan pada data sekunder antara lain konvensi internasional, peraturan perundang-undangan, buku, jurnal hukum dan dokumen hukum lainnya dengan didukung oleh data primer yang terkait dengan objek penelitian. Data kemudian dioalah dengan metode deskriptif-analitis yaitu memamparkan ketentuan divestasi saham pada penambangan bawah tanah 
menurut PP 77/2014 dan dianalisa dengan konsep kedaualatan negara atas sumber daya alam.

\section{Tinjauan Pustaka}

\section{Pengertian Divestasi Saham}

Istilah divestasi berasal dari dua suku kata, yaitu 'divestasi' dan 'saham'. Istilahistilah yang digunakan dalam peraturan perundang-undangan itu meliputi: ${ }^{4}$

a. Partisipasi bagi modal nasional;

b. Pengalihan saham atau menjual saham;

c. Divestasi;

d. Divestasi saham;

Pengertian divestasi dalam terminologi ekonomi sebagaimana dikemukakan oleh Antoni K. Muda adalah penyertaan atau pelepasan sebuah investasi, seperti pelepasan saham oleh pemilik saham lama, tindakan penarikan kembali penyertaan modal yang dilakukan perusahaan modal ventura dari perusahaan pasangan usahanya. ${ }^{5}$ Sedangkan menurut Jeff Madura, divestasi merupakan pengurangan beberapa jenis aset baik dalam bentuk finansial atau barang, dapat pula disebut penjualan dari bisnis yang dimiliki oleh perusahaan sebagai kebalikan dari investasi pada asset yang baru. ${ }^{6}$ Adapun pengertian divestasi saham menurut Pasal 1 Angka (8) PP 23/2010 adalah jumlah saham asing yang harus ditawarkan untuk dijual kepada peserta Indonesia. Terkait definisi divestasi dalam PP 23/2010, menurut Salim H.S. bahwa definisi divestasi saham dalam PP 23/2010 tidak jelas karena tidak tampak pihak-pihak yang mengadakan divestasi saham, tidak tampak jumlah saham yang harus didivestasi, dan bentuk transaksi divestasinya hanya jual beli. Pengalihan saham dapat dilakukan dengan cara jual beli, pinjam meminjam uang, hibah; dan/atau cara lainnya. Oleh sebab itu, pengertian divestasi saham perlu dilengkapi dan disempurnakan menjadi pengalihan sejumlah saham dari penanam modal asing kepada pihak lainnya, baik secara langsung maupun lelang, dengan tujuan untuk meningkatkan kesejahteraan masyarakat. ${ }^{7}$

\section{Para Pihak dalam Divestasi Saham Penanaman Modal Asing}

Pasal 112 UU Minerba menyebutkan 2 (dua) pihak yang terikat dalam transaksi divestasi saham, yaitu:

a. Penanam modal asing asing yang bergerak dalam bidang pertambangan; dan

b. Pihak lainnya.

\footnotetext{
Salim H.S., Hukum Divestasi di Indonesia, Jakarta: PT Penerbit Erlangga, 2010, hlm. 102. Antoni K. Muda, Kamus Lengkap Ekonomi, Jakarta: Gita Media Press, 2003, hlm. 117. Salim H.S., Op.cit., hlm. 32. Ibid., hlm. 102-103.
} 
Penanam modal asing dapat berupa perseorangan warga negara asing, badan usaha asing dan/atau pemerintah negara asing yang melakukan penanaman modal di wilayah Negara Republik Indonesia, ${ }^{8}$ sedangkan pihak lainnya telah ditentukan secara berurutan dengan prioritas untuk didahulukan dalam divestasi saham yaitu: ${ }^{9}$
a. Pemerintah;
b. Pemerintah Daerah;
c. Badan Usaha Milik Negara (BUMN);
d. Badan Usaha Milik Daerah (BUMD);
e. Badan Usaha Swasta Nasional.

\section{Objek Divestasi Pertambangan Mineral dan Batu Bara}

Objek divestasi saham pertambangan mineral dan batu bara adalah aset atau saham yang dimiliki oleh penanam modal asing pada badan usaha pemegang IUP Operasi Produksi dan IUPK Operasi Produksi pada pertambangan mineral dan batu bara. Saham adalah benda bergerak dan memberikan hak kepada pemiliknya. ${ }^{10}$ Saham sebagai benda bergerak berkaitan erat dengan pemindahan dan pembebanan jaminan atas saham tersebut dengan menggunakan lembaga fidusia dan gadai, sedangkan kepemilikan saham juga memberikan hak bagi pemegang saham untuk menikmati kegunaan saham itu secara leluasa dan berbuat bebas terhadap saham itu dengan kedaulatan sepenuhnya, asal tidak bertentangan dengan undang-undang, ketertiban umum, dan tidak mengganggu hak orang lain. ${ }^{11}$

Saham menjadi objek divestasi pada pertambangan mineral dan batu bara ditegaskan dalam UU Minerba sebagaimana ditentukan berikut: "badan usaha pemegang IUP Operasi Produksi dan IUPK Operasi Produksi yang sahamnya dimiliki oleh asing wajib melakukan divestasi saham kepada Pemerintah, Pemerintah Daerah, BUMN, BUMD, atau badan usaha swasta nasional setelah 5 (lima) tahun beroperasi". 12

\section{Mekanisme Divestasi Saham Modal Asing Pertambangan Mineral dan Batu Bara \\ PP 77/2014 mengatur mekanisme divestasi saham modal asing pada pertambangan mineral dan batu bara yaitu pemegang IUP Operasi Produksi dan IUPK Operasi Produksi wajib melakukan penawaran secara berjenjang kepada}

\footnotetext{
Pasal 1 Angka 6 Undang-Undang Nomor 25 Tahun 2007 tentang Penanaman Modal (UU Penanaman Modal). Pasal 97 ayat (2) Peraturan Pemerintah Nomor 23 Tahun 2010 tentang Pelaksanaan Kegiatan Usaha Pertambangan Mineral dan Batu Bara.

Pasal 60 ayat (1) Undang-Undang Nomor 40 Tahun 2007 tentang Perseroan Terbatas (UU PT).

Salim H.S., Op.cit., hlm. 41-42.

Pasal 112 ayat (1) UU Minerba.
} 
peserta Indonesia yaitu pemerintah, pemerintah provinsi, dan pemerintah kabupaten/kota setempat, BUMN, BUMD dan badan usaha swasta nasional. ${ }^{13}$ Pertama, penawaran divestasi saham oleh penanam modal asing kepada pemerintah, pemerintah provinsi, dan pemerintah kabupaten/kota. ${ }^{14}$ Apabila pemerintah tidak memiliki minat terhadap penawaran divestasi saham atau tidak ada jawaban dari pemerintah, maka menteri mengkoordinasikan penetapan komposisi divestasi yang akan dibeli oleh pemerintah provinsi dan pemerintah kabupaten/kota. ${ }^{15}$ Ketika pemerintah pusat, pemerintah provinsi, dan pemerintah kabupaten/kota tidak memiliki minat untuk membeli saham yang dimiliki penanam modal asing melalui divestasi saham, maka saham ditawarkan kepada BUMN dan BUMD secara lelang, serta BUMN dan BUMD harus menyatakan keinginannya. Namun, apabila BUMN dan BUMD tidak berminat untuk membeli saham yang didivestasikan, maka saham ditawarkan kepada badan usaha swasta nasional dengan cara lelang. ${ }^{16}$

\section{Penetapan Harga Saham yang Didivestasikan}

PP 23/2010 memuat ketentuan yang menyatakan bahwa mengenai tata cara divestasi saham dan mekanisme penetapan harga saham diatur dengan Peraturan Menteri setelah berkoordinasi dengan instansi terkait. ${ }^{17}$ Untuk melaksanakan ketentuan tersebut, selanjutnya pemerintah menerbitkan Peraturan Menteri Energi dan Sumber Daya Mineral Nomor 27 Tahun 2013 tentang Tata Cara dan Penetapan Harga Divestasi Saham serta Perubahan Penanaman Modal di Bidang Usaha Pertambangan Mineral dan Batu Bara (Permen ESDM 27/2013), di dalam konsiderannya dinyatakan bahwa dalam rangka melaksanakan ketentuan Pasal 99 PP 23/2010 maka perlu adanya pengaturan mengenai tata cara dan penetapan harga divestasi saham. ${ }^{18}$

Penetapan harga saham yang didivestaskan sebagaimana diatur dalam Permen ESDM 27/2013 adalah harga divestasi saham dari pemegang IUP Operasi Produksi atau IUPK Operasi Produksi yang ditawarkan kepada Peserta Indonesia ditetapkan berdasarkan biaya penggantian (replacement cost) atas investasi pemegang IUP Operasi Produksi atau IUPK Operasi Produksi. ${ }^{19}$ Biaya penggantian (replacement

13 Pasal 97 ayat (2) dan ayat (2a) Peraturan Pemerintah Nomor 77 Tahun 2014 tentang Perubahan Ketiga atas Peraturan Pemerintah Nomor 23 Tahun 2010 tentang Pelaksanaan Kegiatan Usaha Pertambangan Mineral dan Batubara (PP 77/2014).

Pasal 97 ayat (8), (8a) dan (8b) PP 77/2014.

Pasal 99 PP 23/2010.

1 Konsideran huruf a Peraturan Menteri Energi dan Sumber Daya Mineral Nomor 27 Tahun 2013 tentang Tata Cara dan Penetapan Harga Divestasi Saham serta Perubahan Penanaman Modal di Bidang Usaha Pertambangan Mineral dan Batu Bara.

19 Pasal 13 ayat (1) Permen ESDM 27/2013. 
cost) atas investasi pemegang IUP Operasi Produksi atau IUPK Operasi Produksi berupa biaya penggantian (replacement cost) atas jumlah kumulatif biaya investasi yang dikeluarkan sejak tahap eksplorasi sampai dengan tahun kewajiban divestasi saham dikurangi: ${ }^{20}$

a. akumulasi penyusutan dan amortisasi yang didasarkan atas umur ekonomis atau manfaat dari golongan harta yang berbeda-beda yang disesuaikan dengan pengaruh inflasi; dan

b. kewajiban keuangan hingga akhir tahun saat kewajiban divestasi saham jatuh tempo.

Terkait dengan harga divestasi saham, lebih lanjut Permen ESDM 27/2013 menyatakan bahwa harga divestasi saham menjadi: a. harga tertinggi untuk penawaran kepada Pemerintah, Pemerintah Provinsi, dan Pemerintah Kabupaten/Kota; b. harga tertinggi sebagaimana dimaksud pada huruf a merupakan harga dasar untuk penawaran kepada BUMN, BUMD, dan Badan Usaha Swasta Nasional dengan cara lelang. ${ }^{21}$

Adapun dalam perhitungan harga divestasi saham, sebagaimana ditentukan dalam Pasal 14 Permen ESDM 27/2013, bahwa harga divestasi saham yang ditawarkan kepada Peserta Indonesia dapat dihitung oleh Penilai Independen. Pasal 1 angka 14 Permen ESDM 27/2013 menjelaskan yang dimaksud dengan Penilai Independen adalah perusahaan penilai yang tidak terkait dengan bank dan debitur untuk melakukan kegiatan penilaian berdasarkan Kode Etik Penilai Indonesia serta ketentuan-ketentuan lain yang ditetapkan oleh Dewan Penilai Indonesia dan memiliki izin usaha dari instansi yang berwenang.

\section{Teori Kedaulatan Negara di Bidang Ekonomi}

Charter of Economic Right and Duties of State (CERDS) mengakui adanya kedaulatan negara terutama dalam bentuk-bentuk pengurusan kepentingan wilayah dan rakyatnya. Kedaulatan berarti kekusaan tertinggi yang hanya dimiliki negara, ${ }^{22}$ yaitu kekuasaan tertinggi yang dimiliki oleh suatu negara untuk secara bebas melakukan berbagai kegiatan sesuai kepentingannya sepanjang kegiatan tersebut tidak bertentangan dengan hukum internasional. ${ }^{23}$ Hukum internasional telah memberikan yurisdiksi atau hak-hak berdaulat kepada suatu negara untuk

\footnotetext{
Pasal 13 ayat (2) Permen ESDM 27/2013.

Pasal 13 ayat (3) Permen ESDM 27/2013.

22 Schwarzenberger, A Manual of International Law: $5^{\text {th }}$ Edition, Stevens and Sons, 1967, hlm. 64 sebagaimana dikutip oleh Huala Adolf, Hukum Ekonomi Internasional, Jakarta: Raja Grafindo Persada, 2005, hlm. 243.

23 Boer Mauna, Hukum Internasional (Pengertian, Peranan dan Fungsi dalam Era Dinamika Global) Edisi Kedua, Bandung: PT Alumni, 2005, hlm. 24.

24 I. Seidl Hohenveldern, General Course on Public International Law, sebagaimana dikutip oleh Huala Adolf, Perjanjian Penanaman Modal Dalam Hukum Perdagangan Internasional (WTO), Jakarta: Raja Grafindo Persada, 2004, hlm. 14.
} 
mengatur setiap kegiatan perdagangan atau kegiatan ekonomi diwilayahnya. ${ }^{24}$

Kedaulatan negara memberikan kebebasan bagi setiap negara untuk mengatur kepentingan-kepentingan rumah tangganya sendiri, dalam batas-batas yang ditentukan oleh hukum internasional. ${ }^{25}$ Dalam hal ini, negara sebagai organisasi tertinggi dari bangsa yang diberi kekuasaan untuk mengatur segalanya dan negara berdasarkan kedudukannya memiliki kewenangan untuk membuat peraturan hukum. ${ }^{26}$

Bagi suatu negara, penguasaan terhadap bidang ekonomi tergantung dan ditentukan oleh hukum negara. Kedaulatan menentukan apakah suatu negara mampu mengatur kegiatan ekonomi di dalam negerinya dan melakukan hubungan ekonomi internasionalnya. ${ }^{27}$ Kegiatan ekonomi yang dilakukan oleh negara dapat tersistem dan terstruktur. Sistem dan struktur ekonomi tersebut dilandasi dan diarahkan pada pemberdayaan ekonomi rakyat, bukan ekonomi yang kapitalistik, konglomerasi ataupun monopolistik. ${ }^{28}$ Secara umum, kedaulatan ekonomi internal adalah kekuasaan negara untuk mengorganisasi dirinya secara bebas dan otonomi untuk melaksanakan kekuasaan monopoli dalam wilayahnya. ${ }^{29}$ Dalam hal ini, kedaulatan ekonomi sebagai kekuasaan tertinggi suatu negara untuk mengatur kebijakan ekonomi diwilayahnya ataupun kebijakan ekonomi internasionalnya. ${ }^{30}$ Dalam kaitannya antara kedaulatan ekonomi dengan aktivitas penanaman modal di wilayah suatu negara, terdapat pandangan bahwa kebijakan penanam modal bersifat non-cross border issues sehingga pengaturan penanaman modal tunduk sepenuhnya pada kedaulatan internal negara tuan rumah (host country), dan host country memiliki kebebasan luas untuk menetapkan peraturan penanaman modal yang sesuai dengan kebutuhan pembangunan nasionalnya. ${ }^{31}$

\section{Pembahasan}

Pasal 5 ayat (2) Undang-Undang Nomor 25 Tahun 2007 tentang Penanaman Modal (UU Penanaman Modal) menentukan bahwa "penanaman modal asing wajib dalam bentuk perseroan terbatas berdasarkan hukum Indonesia dan berkedudukan di dalam wilayah Negara Republik Indonesia, kecuali ditentukan lain oleh undang-

T. May Rudi, Hukum Internasional 2, Bandung: Refika Aditama, 2006, hlm. 138.

26 Van Vollenhoven sebagaimana dikutip oleh Notonagoro, Politik Hukum dan Pembangunan Agraria di Indonesia, Jakarta: Bina Aksara, 1984, hlm. 4.

27 CF. Ronald A. Brand, "External Sovereignty and International Law", Fordham International Law Journal, 16851697, sebagaimana dikutip oleh Huala Adolf, Hukum Ekonomi Internasional, Op.cit., hlm. 241.

28 Bagir Manan dan Susi Dwi Harijanti, Saat Rakyat Bicara: Demokrasi dan Kesejahteraan, Padjadjaran Jurnal IImu Hukum, Volume 1, Nomor 1, 2014, hlm. 14.

29 Asif Qureshi, International Economic Law, London: Swee and Maxwell, 1999, hlm. 34, sebagaimana dikutip oleh Huala Adolf, Hukum Ekonomi Internasional, Op.cit., hlm. 247.

30 Huala Adolf, Ibid., hlm. 245.

31 Mahmul Siregar, "UUPM dan Penyelesaian Sengketa Perdagangan Internasional dalam Kegiatan Penanaman Modal", Jurnal Hukum Bisnis, Volume 26, Nomor 4, 2007, hlm. 22-25. 
undang", selanjutnya Pasal 5 ayat (3) menegaskan bahwa "penanaman modal dalam negeri dan asing yang melakukan penanaman modal dalam bentuk perseroan terbatas dilakukan dengan: a. mengambil bagian saham pada saat pendirian perseroan terbatas; b. membeli saham; dan c. melakukan cara lain sesuai dengan ketentuan peraturan perundang-undangan.

Atas saham yang dimiliki, Undang-Undang Nomor 40 Tahun 2007 tentang Perseroan Terbatas (UU PT) menyatakan bahwa pemegang saham diberi bukti pemilikan saham untuk saham yang dimilikinya, ${ }^{32}$ dengan mana setiap saham memberikan kepada pemiliknya hak yang tidak dapat dibagi. ${ }^{33}$ Hak yang diperoleh pemegang saham yaitu: ${ }^{34}$

1. Menghadiri dan mengeluarkan suara dalam Rapat Umum Pemegang Saham (RUPS);

2. Menerima pembayaran dividen dan sisa kekayaan hasil likuidasi;

3. Menjalankan hak lainnya berdasarkan undang-undang ini.

Mengacu pada ketentuan UU PT, maka pemegang saham memiliki hak yang diperoleh atas saham yang dimiliki, yang besar dan kecilnya hak tersebut sangat tergantung pada besar dan kecil saham yang dimliki. Dengan demikian, apabila dikaitkan dengan kepemilikan saham pada badan usaha pertambangan mineral dan batu bara, maka besar dan kecil jumlah saham yang dimiliki oleh peserta nasional akan mempengaruhi besar dan kecil hak peserta nasional yang diperoleh dari saham yang dimiliki pada badan usaha pertambangan dan mineral tersebut. Dalam teori divestasi saham, menurut Erman Rajagukguk, penggunaan istilah divestment memiliki kaitannya dengan Indonesianisasi. ${ }^{35}$ Divestasi diartikan tidak hanya pengalihan keuntungan, tetapi yang lebih penting adalah pengalihan kontrol terhadap jalannya perusahaan. Keuntungan yang diperoleh berupa dividen, dan apabila saham dimiliki oleh mitra lokal sebagai pemegang saham mayoritas, maka mitra lokal dapat mengendalikan jalannya perusahaan tersebut dengan jajaran direksi dapat ditempatkan oleh orang-orang lokal. ${ }^{36}$

Budiman Ginting berpendapat bahwa perlindungan hukum untuk pemegang saham minoritas bagi penanam modal Indonesia atau penanam modal asing banyak bergantung kepada seberapa jauh besarnya saham minoritas tersebut. Tidak semua pemegang saham Indonesia berkedudukan sebagai pemegang saham minoritas, tetapi ada yang berkedudukan sebagai pemegang saham mayoritas, dengan mana persentase saham yang dimiliki akan mempengaruhi posisi mereka dalam

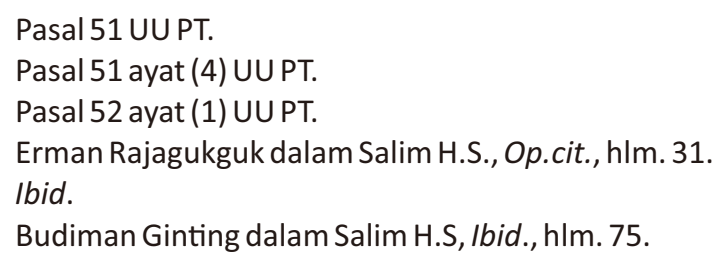


mengawasi dan mengelola perusahaan. ${ }^{37}$

Pemilik saham dalam perseroan memberikan kedudukan berupa: ${ }^{38}$

1. Partisipasi dalam RUPS yang diselenggarakan perseroan serta berhak atas dividen sepanjang perseroan masih berlangsung;

2. Partisipasi atas sisa aset hasil likuidasi perseroan, apabila perseroan dibubarkan.

Ketentuan divestasi saham menurut PP 77/2014 menyatakan bahwa badan usaha pemegang IUP Operasi Produksi dan IUPK Operasi Produksi yang melakukan kegiatan penambangan dengan menggunakan metode penambangan bawah tanah wajib setelah akhir tahun kelima sejak berproduksi paling sedikit sebagai berikut: a. tahun keenam 20\% (dua puluh persen); b. tahun kesepuluh 25\% (dua puluh lima persen); dan c. tahun kelima belas 30\% (tiga puluh persen), dari jumlah seluruh saham. Ketentuan ini memberi peluang bagi penanam modal asing untuk tetap dapat menguasai saham sebanyak $70 \%$ (tujuh puluh persen), dari jumlah seluruh saham. Jika penanam modal asing tetap memiliki sahamnya secara maksimal sebanyak 70 (tujuh puluh persen) dari jumlah seluruh saham, maka pada tahun kelima belas, peserta nasional hanya akan memiliki jumlah saham sebesar 30\% (tiga puluh persen) saham dari jumlah seluruh saham.

Ketentuan ini sangat memberi kemungkinan posisi peserta nasional sebagai pemegang saham minoritas saja. Peserta nasional dimungkinkan hanya memiliki saham paling sedikit 30\% (tiga puluh persen) dalam kegiatan usaha penambangan bawah tanah sedangkan paling banyak $70 \%$ (tujuh puluh persen) saham dapat dimiliki penanam modal asing dalam perseroan. Akibat hukumnya, hak-hak peserta nasional sebagai pemegang saham minoritas lebih kecil dibandingkan dengan hakhak atas saham yang dimiliki oleh penanam modal asing dengan menguasai saham sebesar $70 \%$ (tujuh puluh persen).

Pengambilan keputusan untuk menjalankan badan usaha pertambangan mineral dan batu bara akan sangat dipengaruhi oleh kepentingan penanam modal asing sebagai pemegang saham mayoritas, hal ini terkait dengan keputusan yang dihasilkan dalam RUPS jika saham mayoritasnya dimiliki oleh penanam modal asing maka sangat mengadopsi kepentingan penanam modal asing, sebaliknya bagi peserta nasional tidak memiliki posisi tawar (bargaining position) yang cukup kuat untuk menentukan jalannya badan usaha tersebut dikarenakan memiliki proporsi suara kecil dalam RUPS.

Selain itu, terkait dengan perolehan dividen bagi pemegang saham dari badan usaha pertambangan mineral dan batu bara, besar dan kecil dividen yang diperoleh juga sangat ditentukan oleh besar dan kecil jumlah saham yang dimiliki oleh pemegang saham. Ketentuan divestasi saham PP 77/2014 memungkinkan 
penanam modal asing tetap dapat menguasai saham secara maksimal sebanyak $70 \%$ (tujuh puluh persen), dari jumlah seluruh saham, sedangkan sisanya sebesar $30 \%$ (tiga puluh persen) saja dari jumlah seluruh saham menjadi milik peserta nasional, maka hanya sebesar $30 \%$ (tiga puluh persen) jumlah dividen yang diterima oleh peserta nasional dari keseluruhan dividen yang diperoleh badan usaha pertambangan mineral tersebut. Sedangkan 70\% (tujuh puluh persen) dari jumlah keseluruhan dividen akan dinikmati oleh penanam modal asing. Padahal dividen yang diperoleh dari badan usaha merupakan sumber pendapatan nasional yang dapat digunakan untuk pembangunan nasional.

Berdasarkan hal tersebut, jumlah saham minimal yang dimiliki oleh peserta nasional sebesar $30 \%$ (tiga puluh persen) pada badan usaha penambangan mineral dan batu bara yang menggunakan metode penambangan bawah tanah sebagaimana diatur oleh PP 77/2014 kurang mewakili kepentingan negara dalam rangka melaksanakan amanat Pasal 33 UUD 1945. Sebaliknya, penanam modal asing akan lebih diuntungkan dengan kemungkinannya menjadi pemegang saham mayoritas apabila dibandingkan dengan ketentuan divestasi saham menurut PP 24/2012 yang menentukan bahwa pemegang IUP dan IUPK dalam rangka penanaman modal asing, setelah 5 (lima) tahun sejak berproduksi wajib melakukan divestasi sahamnya paling sedikit 51\% (lima puluh satu persen) dimiliki peserta Indonesia. Ketentuan divestasi saham dalam PP 24/2012 menempatkan peserta nasional sebagai pemegang saham mayoritas dengan menguasai saham lebih dari setengah saham yang dimiliki oleh badan usaha pertambangan mineral dan batu bara tersebut. Sebaliknya, penanam modal asing menjadi pemegang saham minoritas dengan jumlah saham paling banyak $49 \%$ (empat puluh sembilan persen).

Ketentuan dalam PP 24/2012 semakin memperkuat superioritas negara terhadap perusahaan asing, dalam hal ini kebijakan divestasi telah menempatkan paradigma penguasaan negara atas sumber daya mineral dan batu bara di jalur yang benar untuk mencapai negara kesejahteraan. ${ }^{39}$ Penjelasan Umum PP 24/2012 secara tegas menyatakan bahwa dalam rangka keberpihakan kepada peserta Indonesia untuk lebih berpartisipasi di bidang pengusahaan pertambangan dan batu bara, perlu mewajibkan modal asing untuk mengalihkan sebagian sahamnya kepada peserta Indonesia. ${ }^{40}$

Kepemilikan saham melalui penguasaan negara atas sumber daya alam adalah memberi nilai tambah secara nyata bagi perekonomian nasional dalam usaha

39 Victor Imanuel Williamson Nalle, "Hak Menguasai Negara Atas Mineral dan Batu Bara Pasca Berlakunya Undang-Undang Minerba”, Jurnal Konstitusi, Volume 9, Nomor 3, September 2012, hlm. 490-491, diakses 13 September 2016, https://ejournal:mahkamahkonstitusi.go.id/index.php/jk/article/viewFile/140/139.

40 Penjelasan Umum PP 24/2012.

41 Mercy Maria Magdalena Setlight, "Divestasi Sebuah Langkah Progresif Dalam Kontrak Karya Di Indonesia", Jurnal Hukum PRIORIS, Volume 5, Nomor 1, 2015, hlm. 28, diakses 13 September 2016, http://trijurnal.lemlit.trisakti.ac.id/index.php/prioris/article/download/397/366. 
mencapai kemakmuran dan kesejahteraan rakyat secara berkeadilan. Manfaat yang akan didapatkan dari divestasi secara nyata bagi Indonesia adalah adanya bagian dividen dari saham yang dibelinya, kemudian dari dividen yang diterima itulah akan digunakan untuk meningkatkan kesejahteraan masyarakat. Kewajiban divestasi saham kepada peserta Indonesia sebesar 51\% (lima puluh satu persen) telah sesuai dengan tujuan UUD 1945 sebagaimana dimaksud dalam Pasal 33 ayat (3) yang menyebutkan bahwa bumi, air dan kekayaan alam yang terkandung di dalamnya dikuasai oleh negara dan dipergunakan untuk sebesar-besarnya kemakmuran rakyat. $^{41}$

Penguasaan dan pengelolaan penambangan bawah tanah nasional seharusnya diwujudkan dengan memperbesar keterlibatan peserta nasional dalam pemilikan saham sebagai pemegang saham mayoritas. Asif Qureshi berpendapat bahwa terdapat 4 (empat) dalil kekuasaan yang dimiliki negara dalam bidang ekonomi, yaitu: 42

1. Suatu negara memiliki kedaulatan permanen terhadap kekayaan alamnya;

2. Suatu negara memiliki kedaulatan terhadap kekayaan non-alam atau kegiatan ekonominya di dalam wilayah yurisdiksinya, termasuk sumber daya manusia;

3. Suatu negara memiliki hak untuk memilih dan melaksanakan sistem ekonominya; dan

4. Suatu negara memiliki kewajiban untuk tidak turut campur dalam urusan ekonomi negara lainnya melalui ancaman atau kekerasan.

Sjahran Basah mengemukakan bahwa Negara Indonesia menganut konsep negara hukum modern atau negara kesejahteraan yang memiliki tujuan untuk mewujudkan masyarakat yang adil dan makmur baik materiil maupun spiritual berdasarkan Pancasila dan UUD 1945, sehingga disebut Negara hukum Pancasila. ${ }^{43}$ Terkait dengan hal tersebut, terdapat beberapa fungsi atau tugas Negara Indonesia yaitu: ${ }^{44}$

1. Fungsi keamanan, pertahanan, dan ketertiban (defence, security, and protection). Termasuk ke dalam fungsi ini adalah fungsi perlindungan terhadap kehidupan, hak milik, dan hak-hak lainnya sesuai dengan yang diatur dalam peraturan perundang-undangan;

2. Fungsi kesejahteraan (welfare function), termasuk kedalamnya social service dan social welfare. Seluruh kegiatan yang ditujukan untuk terwujudnya kesejahteraan masyarakat serta keadilan sosial bagi seluruh rakyat Indonesia;

3. Fungsi pendidikan (educational function), termasuk tugas penerangan umum,

42 Asif Qureshi dalam Huala Adolf, Op.cit., hlm. 247-248.

43 Sjahran Basah, Eksistensi dan Tolok Ukur Badan Peradilan Administrasi di Indonesia, Cetakan Kedua, Bandung: Alumni, 1983, hlm. 11.

44 Muchsan, Sistem Pengawasan terhadap Perbuatan Aparat Pemerintah dan Peradilan Tata Usaha Negara di Indonesia, Cetakan Kedua, Yogyakarta: Liberty, 2000, hlm. 16, sebagaimana dikutip oleh Ida Nurlinda, PrinsipPrinsip Pembaharuan Agraria Perspektif Hukum, Jakarta: Raja Grafindo Persada, 2009, hlm. 6. 
nation and character building, peningkatan budaya, dan lain-lain;

4. Fungsi mewujudkan ketertiban dan kesejahteraan dunia (world peace and human welfare) dalam artiluas.

Menurut Bagir Manan, dalam upaya untuk menciptakan kemakmuran bagi rakyat, negara memiliki kewajiban dalam hal: ${ }^{45}$

1. Segala bentuk pemanfaatan (bumi dan air) serta hasil yang didapat (kekayaan alam), harus secara nyata meningkatkan kemakmuran dan kesejahteraan masyarakat;

2. Melindungi dan menjamin segala hak-hak rakyat yang terdapat di dalam atau di atas bumi, air dan berbagai kekayaan alam tertentu yang dapat dihasilkan secara langsung atau dinikmati langsung oleh rakyat, dan

3. Mencegah segala tindakan dari pihak manapun yang akan menyebabkan rakyat tidak mempunyai kesempatan atau akan kehilangan haknya dalam menikmati kekayaan alam.

Pengelolaan sumber daya alam yang dilakukan dan diusahakan oleh negara bermuara pada satu tujuan yaitu menciptakan sebesar-besar kemakmuran rakyat. Tujuan itu menjadi tanggung jawab negara sebagai bentuk konsekuensi dari hak menguasai negara terhadap bumi, air dan kekayaan alam yang terkandung didalamnya. Hal ini juga merupakan jaminan dan bentuk perlindungan terhadap sebesar-besar kemakmuran rakyat dan kesejehtaraan umum atas dasar keadilan sosial bagi seluruh rakyat Indonesia. ${ }^{46}$ Pasal 33 UUD 1945 telah menegaskan bahwa "cabang-cabang produksi yang penting bagi negara dan yang menguasai hajat hidup orang banyak dikuasai oleh negara" (ayat 2), dan pada ayat (3) bahwa, "Bumi, air dan kekayaan alam yang terkandung didalamnya dikuasai oleh negara dan dipergunakan untuk sebesar-besar kemakmuran rakyat".

Kandungan makna pada ayat (2) dan ayat (3) Pasal 33 UUD 1945, dalam kalimat 'menguasai hajat hidup orang banyak' dan 'digunakan untuk sebesar-besanya kemakmuran rakyat' merupakan ekspresi adanya orientasi kerakyatan yang kuat. Dalam hal ini, untuk cabang-cabang produksi yang penting bagi negara dan terkait dengan hajat hidup orang banyak, maka cabang-cabang produksi tersebut perlu benar-benar 'dikuasai oleh negara', dengan tujuan utama pengamanan kepentingan rakyat banyak. ${ }^{47}$

Perkataan 'dikuasai oleh negara' tidak lain adalah penguasaan dalam arti yang luas, yaitu mencakup pengertian kepemilikan dalam arti publik dan sekaligus perdata, termasuk pula kekuasaan dalam mengendalikan dan mengelola bidang-

45 Bagir Manan, dkk, Pertumbuhan dan Perkembangan Konstitusi Suatu Negara, Bandung: Mandar Maju, 1995, hlm. 17.

46 Winahyu Erwiningsih, Hak Menguasai Negara Atas Tanah, Yogyakarta: Total Media, 2009, hlm. 82.

47 Abdul Madjid dan Sri Edi Swasono (ed), Wawasan Ekonomi Pancasila, Jakarta: Penerbit Universitas Indonesia, 1998, hlm. 17. 
bidang usaha itu secara langsung oleh pemerintah atau aparat-aparat pemerintahan yang dibebani dengan tugas khusus. Akan tetapi, mesti dibedakan antara pengertian yang bersifat prinsip bahwa pemerintah sendiri menjadi pemilik dan pelaku usaha tersebut dengan persoalan bentuk organisasi pengelolaannya di lapangan. ${ }^{48}$

Makna 'dikuasai oleh negara' berarti bahwa rakyat secara kolektif dikonstruksikan oleh UUD 1945 memberikan mandat kepada negara untuk melakukan kebijakan (beleid) dan tindakan pengurusan (bestuursdaad), pengaturan (regelendaad), pengelolaan (beheersdaad), dan pengawasan (toezichthoudensdaad) untuk sebesar-besar kemakmuran rakyat. Fungsi pengurusan (bestuursdaad) oleh negara dilakukan oleh pemerintah dan kewenangannya untuk mengeluarkan dan mencabut fasilitas perizinan (vergunning), lisensi (licentie), dan konsesi (concessie). Fungsi pengaturan (regelendaad) oleh negara dilakukan melalui kewenangan legislasi oleh DPR bersama dengan pemerintah dan regulasi oleh pemerintah (eksekutif). Fungsi pengelolaan (beheersdaad) dilakukan melalui pendayagunaan penguasaan negara atas sumber-sumber kekayaan untuk digunakan bagi sebesar-besar kemakmuran rakyat. Demikian pula fungsi pengawasan (toezichthoudensdaad) yang dilakukan oleh negara melalui pemerintah dalam rangka mengawasi dan mengendalikan agar pelaksanaan penguasaan oleh negara atas cabang produksi yang penting dan/atau yang menguasai hajat hidup orang banyak dimaksud benar-benar dilakukan untuk sebesar-besar kemakmuran seluruh rakyat. ${ }^{49}$ Dikuasai oleh negara memaknai hak penguasaan negara atas aset kekayaan alam. Negara berdaulat mutlak atas kekayaan sumber daya alam. Digunakan untuk sebesar-besarnya kemakmuran rakyat dimaknai hak kepemilikan yang sah atas kekayaan alam adalah rakyat Indonesia. ${ }^{50}$

Oleh karena itu, pada prinsipnya, pemilik usaha tersebut haruslah pemerintah sehingga jalannya perusahaan dapat dikuasai, dikendalikan, dan dapat pula dikelola sendiri oleh aparat pemerintah. Namun, dalam perkembangannya saham perusahaan itu dapat saja dijual langsung atau pun melalui pasar modal, tetapi dalam jumlah sedemikian rupa sehingga kendali perusahaan itu tetap berada di tangan pemerintah. Artinya, meskipun sebagian sahamnya tidak dimiliki oleh pemerintah, tetapi perusahaan tersebut tetap berada di tangan pemerintah. ${ }^{51}$ Dalam konteks hukum publik dan sekaligus hukum perdata, pengertian 'dikuasai

48 Jimly Asshiddiqie, Konstitusi Ekonomi, Jakarta: Penerbit Buku Kompas, 2010, hlm. 272.

49 Putusan Mahkamah Konstitusi Republik Indonesia Nomor: 21-22/PUU-V/2007.

50 Adrian Sutedi, Hukum Pertambangan, Jakarta: Sinar Grafika, 2012, hlm. 25, dalam Henry Donald Lbn.Toruan, "Pergeseran Paradigma Hukum Investasi Pertambangan", Jurnal RechtsVinding, Volume 4, Nomor 2, Agustus 2015, hlm. 270, diakses 13 September 2016, http://rechtsvinding.bphn.go.id/artikel/ART\%205\%20JRV\%204$.2 \% 20$ WATER.pdf

51 Jimly Asshiddiqie, Op.cit., hlm. 273. 
oleh negara' adalah penguasaan dalam arti yang seutuhnya yang mencakup juga makna kepemilikan, yaitu kepemilikan dalam pengertian hukum publik yang tentunya berfungsi sebagai sumber pengertian kepemilikan perdata (private ownership). Dengan dikuasai oleh negara, maka kekayaan sumber daya alam yang dimiliki seluruhnya adalah untuk kepentingan rakyat. ${ }^{52}$

Berdasarkan hal tersebut, pada penguasaan dan pengelolaan oleh negara terhadap sumber daya alam pada sektor yang sifatnya strategis bagi kemakmuran rakyat yang salah satunya adalah sektor pertambangan mineral dan batu bara mengacu pada Pasal 33 ayat (2) dan ayat (3) UUD 1945, dan juga apabila dihubungkan dengan teori dan ketentuan Hukum Ekonomi Internasional mengenai kedaulatan negara di bidang ekonomi dalam rangka penguasaan dan pengelolaan sumber daya alam terdapat di wilayah negara, maka dalam penguasaan dan pengelolaan pertambangan mineral dan batu bara nasional, semestinya fungsi dan peran pemerintah, pemerintah daerah, BUMN, BUMD, dan Badan Usaha Swasta Nasional lebih besar dibandingkan dengan penanam modal asing.

\section{E. Penutup}

Berdasarkan pembahasan tersebut di atas, dapat diperoleh kesimpulan sebagai berikut:

1. Perubahan jumlah saham minimal milik penanam modal asing pada badan usaha pertambangan mineral dan batu bara yang menggunakan metode penambangan bawah tanah yang sebelumnya diatur dalam PP 24/2012 dan diubah melalui PP 77/2014 yaitu 51\% (lima puluh satu persen) menjadi minimal $30 \%$ (tiga puluh persen) telah berimplikasi secara hukum terhadap besar saham milik peserta nasional menjadi lebih kecil, sehingga penanam modal asing lebih diuntungkan karena memiliki kesempatan menjadi pemegang saham mayoritas dengan jumlah maksimal 70\% (tujuh puluh persen) dari jumlah seluruh saham sehingga akan memegang kendali jalannya badan usaha tersebut, memiliki suara dominan dalam pengambilan keputusan melalui RUPS serta memperoleh dividen yang lebih besar dibandingkan dengan peserta nasional.

2. Ketentuan PP $77 / 2014$ dalam hal kewajiban divestasi saham modal asing pada badan usaha pertambangan mineral dan batu bara yang menggunakan metode penambangan bawah tanah kurang mencerminkan adanya kedaulatan negara dalam hal penguasaan dan pengelolaan ekonomi sebagaimana dimaksud dalam konsep kedaulatan negara dalam pengelolaan sumber daya alam menurut Hukum Ekonomi Internasional yaitu pemanfaatan sumber daya alam yang berada dalam teritorial suatu negara, di mana negara tersebut memiliki kedaulatan untuk secara bebas menguasai dan mengelola kekayaan alamnya

$52 \quad$ Ibid., hlm. 281. 
untuk kepentingan negara yang bersangkutan tanpa dapat diintervensi oleh pihak manapun. Demikian pula, sebagaimana dilandasi oleh Pasal 33 UUD 1945, maka semestinya negara melalui keterlibatan peran pemerintah, pemerintah daerah, BUMN, BUMD atau badan usaha swasta menjadi pemegang saham mayoritas sebagai cerminan dari penguasaan dan pengelolaan sumber daya alam pertambangan mineral dan batu bara nasional untuk sebesar-besar kemakmuran rakyat, sehingga bukan untuk keuntungan penanam modal asing.

\section{Daftar Pustaka}

\section{Buku}

Abdul Madjid dan Sri Edi Swasono (ed), Wawasan Ekonomi Pancasila, Penerbit Universitas Indonesia, Jakarta, 1998.

Antoni K. Muda, Kamus Lengkap Ekonomi, Gita Media Press, Jakarta, 2003.

Bagir Manan, dkk, Pertumbuhan dan Perkembangan Konstitusi Suatu Negara, Mandar Maju, Bandung, 1995.

Boer Mauna, Hukum Internasional (Pengertian, Peranan dan Fungsi dalam Era Dinamika Global) Edisi Kedua, Alumni, Bandung, 2005.

Huala Adolf, Hukum Ekonomi Internasional, Raja Grafindo Persada, Jakarta, 2005. , Perjanjian Penanaman Modal Dalam Hukum Perdagangan Internasional (WTO), Raja Grafindo Persada, Jakarta, 2004.

Ida Nurlinda, Prinsip-Prinsip Pembaharuan Agraria PerspektifHukum, Raja Grafindo Persada, Jakarta, 2009.

Jimly Asshiddiqie, Konstitusi Ekonomi, Jakarta, Penerbit Buku Kompas, 2010.

M. Yahya Harahap, Hukum Perseroan Terbatas Cetakan Pertama, Sinar Grafika, Jakarta, 2009.

Muchsan, Sistem Pengawasan terhadap Perbuatan Aparat Pemerintah dan Peradilan Tata Usaha Negara di Indonesia, Cetakan Kedua, Liberty, Yogyakarta, 2000.

Notonagoro, Politik Hukum dan Pembangunan Agraria di Indonesia, Bina Aksara, Jakarta, 1984.

Sjahran Basah, Eksistensi dan Tolok Ukur Badan Peradilan Administrasi di Indonesia, Cetakan Kedua, Alumni, Bandung, 1983.

Salim H.S., Hukum Divestasi di Indonesia, Erlangga, Jakarta, 2010.

T. May Rudi, Hukum Internasional 2, Refika Aditama, Bandung, 2006.

Winahyu Erwiningsih, Hak Menguasai Negara atas Tanah, Total Media, Yogyakarta, 2009.

\section{Dokumen Lain}

Bagir Manan dan Susi Dwi Harijanti, "Saat Rakyat Bicara: Demokrasi dan 
Kesejahteraan", Padjadjaran Jurnal Ilmu Hukum, Volume 1, Nomor 1, 2014.

Henry Donald Lbn.Toruan, "Pergeseran Paradigma Hukum Investasi

Pertambangan", Jurnal RechtsVinding, Volume 4, Nomor 2, Agustus 2015, http://rechtsvinding.bphn.go.id/-artikel/ART\%205\%20JRV\%204.2\%20WATER.pdf, diakses 13 September 2016.

Mahmul Siregar, "UUPM dan Penyelesaian Sengketa Perdagangan Internasional dalam Kegiatan Penanaman Modal", Jurnal Hukum Bisnis, Volume 26, Nomor 4, 2007.

Mercy Maria Magdalena Setlight, "Divestasi Sebuah Langkah Progresif Dalam Kontrak Karya Di Indonesia", Jurnal Hukum PRIORIS, Volume 5, Nomor 1, 2015, http://trijurnal.lemlit.trisakti.ac.id/index.php/prioris/article/download/397/3 66, diakses 13 September 2016.

Victor Imanuel Williamson Nalle, "Hak Menguasai Negara Atas Mineral dan Batu Bara Pasca Berlakunya Undang-Undang Minerba", Jurnal Konstitusi, Volume 9, Nomor 3, September 2012, https://ejournal:mahkamahkonstitusi.go.id/index.php/jk/article/viewFile/140/139, diakses 13 September 2016.

\section{Dokumen Hukum}

Undang-Undang Dasar Negara Republik Indonesia Tahun 1945.

Undang-Undang Nomor 25 Tahun 2007 tentang Penanaman Modal.

Undang-Undang Nomor 40 Tahun 2007 tentang Perseroan Terbatas.

Undang-Undang Nomor 4 Tahun 2009 tentang Pertambangan Mineral dan Batu Bara.

Peraturan Pemerintah Nomor 23 Tahun 2010 tentang Pelaksanaan Kegiatan Usaha Pertambangan Mineral dan Batu Bara.

Peraturan Pemerintah Nomor 24 Tahun 2012 tentang Perubahan atas Peraturan Pemerintah Nomor 23 Tahun 2010 tentang Pelaksanaan Kegiatan Usaha Pertambangan Mineral dan Batubara.

Peraturan Pemerintah Nomor 77 Tahun 2014 tentang Perubahan Ketiga atas

Peraturan Pemerintah Nomor 23 Tahun 2010 tentang Pelaksanaan Kegiatan Usaha Pertambangan Mineral dan Batubara.

Peraturan Menteri Energi dan Sumber Daya Mineral Nomor 27 Tahun 2013 tentang

Tata Cara dan Penetapan Harga Divestasi Saham serta Perubahan Penanaman Modal di Bidang Usaha Pertambangan Mineral dan Batu Bara.

Putusan Mahkamah Konstitusi Republik Indonesia No.21-22/PUU-V/2007.

Resolusi Perserikatan Bangsa-Bangsa Nomor 3281 tentang Charter of Economic Rights and Dutie of State (CERDS). 